\title{
Interview: Mourning Is a Political Act Amid the Pandemic and Its Disparities (Republication)
}

\author{
Judith Butler • George Yancy
}

Accepted: 11 August 2020

(C) Truthout.org 2020, Reprinted with permission

\begin{abstract}
This conversation between a feminist and a critical whiteness scholar addresses the politics of vulnerability to COVID-19 and the questions of what it means to mobilize and learn from private grief and mass mourning and the role of academia and intellectuals in the current crisis.
\end{abstract}

Keywords Pandemic · Public mourning · Global vulnerability $\cdot$ COVID-19 . Mass death $\cdot$ Health disparities

This interview originally appeared on the truthout.org website on April 30, 2020 (Truthout 2020). We thank Truthout for their permission to reprint the interview in full in the Journal of Bioethical Inquiry.

This conversation between a feminist and a critical whiteness scholar addresses the politics of vulnerability to COVID-19 and the questions of what it means to mobilize and learn from private grief and mass mourning and the role of academia and intellectuals in the current crisis.

George Yancy: Trying to articulate what it feels like to live through this shared pandemic is difficult. I move

\footnotetext{
J. Butler

Department of Comparative Literature and the Program of Critical Theory at the University of California, Berkeley, 4125 Dwinelle Hall, Berkeley, CA 94720-2510, USA

e-mail: jpbutler@berkeley.edu

G. Yancy $(\bowtie)$

Department of Philosophy, Emory University, 561 S. Kilgo

Circle, Atlanta, GA 30322, USA

e-mail: george.d.yancy@emory.edu
}

through feelings of profound grief, intolerable isolation and even fantasies of apocalyptic dread. At other times, there is a sense of hope and clarity. One among many things that is very clear to me, though by no means new, is just how interconnected we are, just how misleadingly and dangerously we have behaved and treated others under neoliberal assumptions and practices. We are, after all, as you have argued, "Given over from the start to the world of others." Your point couldn't be more germane as we find ourselves within the midst of an unprecedented global vulnerability. Speak to how you're thinking about vulnerability at this moment, especially in terms of how that vulnerability isn't equally distributed.

Judith Butler: On the one hand, the pandemic exposes a global vulnerability. Everyone is vulnerable to the virus because everyone is vulnerable to viral infection from surfaces or other human beings without establishing immunity. Vulnerability is not just the condition of being potentially harmed by another. It names the porous and interdependent character of our bodily and social lives. We are given over from the start to a world of others we never chose in order to become more or less singular beings. That dependency does not precisely end with adulthood. To survive, we take something in. We are impressed upon by the environment, social worlds and intimate contact. That impressionability and porosity define our embodied social lives. What another breathes out, I can breathe in, and something of my breath can find its way into yet another person. The human trace that someone leaves on an object may well be what I touch, pass along on another surface or absorb into my own body. Humans share the air with one 
another and with animals; they share the surfaces of the world. They touch what others have touched and they touch one another. These reciprocal and material modes of sharing describe a crucial dimension of our vulnerability, intertwinements and interdependence of our embodied social life.

On the other hand, the public response to the pandemic has been to identify "vulnerable groups"- those who are especially likely to suffer the virus as a ravaging and life-threatening disease and to contrast them with those who are less at risk of losing their lives from the pathogen. The vulnerable include Black and Brown communities deprived of adequate health care throughout their lifetimes and the history of this nation. The vulnerable also include poor people, migrants, incarcerated people, people with disabilities, trans and queer people who struggle to achieve rights to health care, and all those with prior illnesses and enduring medical conditions. The pandemic exposes the heightened vulnerability to the illness of all those for whom health care is neither accessible nor affordable. Perhaps there are at least two lessons about vulnerability that follow: it describes a shared condition of social life, of interdependency, exposure and porosity; it names the greater likelihood of dying, understood as the fatal consequence of a pervasive social inequality.

George Yancy: Coupled with your reflections on vulnerability are such themes as mourning and grief. I take very seriously the fact that, at this moment, there are so many who are unemployed. Yet, COVID-19 has made unambiguously clear the deep forms of economic instability that have always been there, that are intrinsic to our ways of living, our ways of being complacent with huge economic differentials, of massive income and wealth gaps. In short, people are mourning and grieving because they are simply not economically secure. How do we mobilize such mourning and grief and tarry with it, so that it has something to teach us now and going forward?

Judith Butler: For those who are homeless or unemployed, the economic forecast could not look bleaker. Without a working and equitable health care system, the affirmation of health care as a public good and a mandate of government, the unemployed are left to scramble for alternatives to avoid falling ill and dying for lack of care. This is the stunning cruelty of the U.S. that shocks large portions of the world. Many workers are not just temporarily out of work, but are registering the collapse of their work worlds, the prospect of no paycheck, homelessness, a pervasive sense of being abandoned by the society to which they should rightly belong.

Before the pandemic, the future horizon was already closing or closed for many people forced to move between jobs, who saw no real increase in wages, and found that rents, debts and medical costs belonged to the expanding category of "the unpayable." Their entire sense of future is structured by that unpayable debt: it becomes a form of bondage, infinite and without end.

The radical increase in poverty now means that anxiety and fear become for many the norm: How will they eat? Will they eat less often and less well? Will they find shelter? How will they survive and those who depend upon them? Many are anxious because they do not yet know who or what they have yet to lose, what parts of the world will be irrecoverably lost or reanimated in new and truncated form. Those grieving now may well be bracing for more grief, not knowing from which direction it will arrive. The grief over the sudden loss of someone's life is bound up with a sense of shock that this is now a world in which such losses can and do and will happen.

George Yancy: Many of my students, both undergraduate and graduate, have been grieving in a different way. Some have said to me that academia feels useless and going to classes during this time just doesn't make sense. In fact, those students in philosophy have been particularly vocal. They are finding it hard to read abstract texts that seem oblivious to our current existential predicament. Any advice?

Judith Butler: Some young people, including students of mine, worry that they are being asked to grieve the loss of hope itself. But theirs is not a mindless desperation. They do not accept the lies and false promises of the profiteers or the politicians that call for reopening of the workplace without any regard for the lives that could not survive the infection.

My graduate students don't make decent wages as it is, often living in overcrowded rental apartments, forced to pay high rents in the Bay Area, and sometimes suffering from food insecurity. Now they are asking what path in academic life is still open for them. They live with a profound uncertainty during this time even as they seek to ground themselves in an informed understanding of the pandemic. They are in urgent need of debt forgiveness and a livable wage and are drawn to strike actions to make their clearly just demands.

As a teacher and adviser, I ponder how to hold steady for the young when one's own foundation is rocked and 
rocking? In higher education, we are confronted with hiring freezes, furloughs, the freezing and cancellation of academic and postdoctoral positions. The arts and the humanities were already struggling for decent funding in a higher education market that tends to reward the STEM fields without seeing how interconnected our kinds of knowledge are.

The basic questions - how to live, how to face mortality and how best to make sense of the world - are ones that drive the humanities still and again. The crisis of values we are facing is enormous as cost-benefit schemes of values are imposed upon the management of life, too often designating the precarious as dispensable lives. It is no wonder that people are turning to poetry and song, writing and visual art, history and theory to make sense of their pandemic world, to reflect upon the question: When the world as we know it falls apart, what then?

George Yancy: I am often speechless when I see the piling up of corpses and makeshift morgues as so many of us perish as a result of this pandemic. Often after a mass shooting, even if it is forgotten soon thereafter, we, in the U.S., engage in public forms of grieving. For many families, burial rituals cannot be performed given the spread of the virus. What deep impact do you think this will have on families and how might we rethink public forms of grieving?

Judith Butler: A difficult question: How to mourn mass death? Under conditions of pandemic, losses are for the most part borne in private. We are returned to the household as the site for mourning, deprived of the public gathering in which such losses are marked and registered and shared. The internet has more fully claimed its place as the new public sphere, but it can never fully substitute for the gatherings, both private and public, that allow losses to be fathomed and lived through with others.

A purely private form of mourning is possible but cannot assuage the cry that wants the world to bear witness to the loss. And with public losses of this magnitude and quick succession, there are political questions that are linked with the demand for public mourning: Why were health facilities so badly underfunded and unprepared? Why did the president disband the committee tasked with preparations of pandemics of this kind? Why are there not enough beds or ventilators? Why are Black people, incarcerated people and migrants more at risk of dying than those who have been afforded decent health care for years? All these lost lives are grievable, which means that they are lives worthy of acknowledgment, equal in value to every other life, a value that cannot be calculated.

The images of bodies piled high in Ecuador or stacked in closets in New Jersey or Northern Italy convey that the infrastructure of hospitals is overwhelmed and underfunded and those conditions were not in place to respect the dead. The images shock; they tell a story about public health infrastructure, demands on health care workers, the emotional cost of social distancing when loved ones cannot receive the body and the dead body becomes a logistical problem: stacked, counted, transferred, stored. The images flit by as sensational clips.

Sequestering enforces both a sense of ambient death and a shared practice of deflection: "Let's not focus on the negative!" Learning to mourn mass death means marking the loss of someone whose name you do not know, whose language you may not speak, who lives at an unbridgeable distance from where you live. One does not have to know the person lost to affirm that this was a life. What one grieves is the life cut short, the life that should have had a chance to live more, the value that person has carried now in the lives of others, the wound that permanently transforms those who live on. What someone else suffers is not one's own suffering, but the loss that the stranger endures traverses the personal loss one feels, potentially connecting strangers in grief.

George Yancy: You know, it seems to me that we are not even allowing ourselves to grieve as a nation. Perhaps this is because so many are dying every day. Then again, for those whom the economy is the bottom line - especially for those who have expressed the desire to give their lives so that the economy is thriving again, which is really just getting back to a state of normal economic instability and precarity-it's not clear to me that they understand the importance of expressing a nonmarket-related grief. Their only grief seems to be related to the fact that the capitalist machine is taking a hit. It's as if many are not undone or un-sutured by the death of other human beings; rather, they are panicked by the fact that capitalism is being upended. What does this say about the moral logics (or lack thereof) regarding some in our country?

Judith Butler: Yes, we see the discourse on "the health of the nation" slide into another on "the health of the economy." But Social Darwinism has taken hold in some circles, especially in the discussions of "herd 
immunity." Some argue that the economy must be reinvigorated even if the virus is left more free to circulate, threatening the lives of the most vulnerable people. That those who are most likely to survive the virus (imagined as young, equipped with health care from the onset of life, able-bodied, white and without preexisting conditions) would go back to work and the university while the rest of us stay sheltering in place rests on a particular kind of lie.

Although some claim that the vulnerable - a new class - would remain "protected" by staying out of the workplace, that simply means the intensification of unemployment for many. And it is no "protection" because those healthy "immunes" will doubtless transfer the virus and affect their communities, including their parents and grandparents, and all those who cannot afford to stay home. Because "the vulnerable" are not deemed productive in the new quasi-Aryan community, they are not valued lives, and if they die, that is apparently acceptable, since they are not imagined as productive workers, but "drains" on the economy. Although the herd immunity argument may not make this claim explicitly, it is there.

To restart the economy without universal health care is to sacrifice the lives of those whose health or health care has never been good. It is to intensify those forms of social and economic inequality that disproportionately affect Black people and all those who qualify as "vulnerable" in the pandemic. It is not enough to point out that the productive worker back in the workplace and the public sphere will probably survive the viral infection, establish immunity, and go on working; that worker is a potential spreader when infected. This is a price that some are willing to pay, but we should look carefully at the ethics and politics of such a decision. For the "health" of the economy, the virus spreads and damages the health of the population, especially those who are precarious and most at risk of dying.

George Yancy: For me, this level of market worshipping and market domination at the expense of collective human life was nauseatingly clear, despicably immoral, especially when I read that Trump allegedly offered German scientists, who were working on a possible coronavirus vaccine, money to acquire exclusive rights to the possible vaccine for the U.S. This sort of move, if true, speaks to the necro-political intersection between cruel and unabashed nationalism, capitalistic greed, and the perverse desire to control who dies and who lives. The thought of this is monstrous. What does this say about differential vulnerability, and those who have already been marked as "grievable" and "un-grievable"?

Judith Butler: I see that there are writers and academics who are taking both utopian and dystopian positions. The utopians tend to celebrate the global timeout as an opportunity to remake the world and to realize the socialist ideals embodied in the communities of care that have recently emerged. I can understand that.

The dystopians tend to project into the future the intensification of state control and surveillance, the loss of civil liberties and the unshackling of market forces, including the crude kinds of market rationality that intensify social and economic inequalities. I can understand that, too.

We are confronting an intensified struggle and the results cannot be predicted. Political anxiety accelerated because conventional forms of mobilization are not available during lockdown. However, some very impressive international exchange is taking place among research institutes seeking to develop a vaccine at the same time that some pharmaceuticals are clearly positioning themselves for obscene profits.

The German company, CureVac, from whom Trump tried to secure exclusive U.S. rights to any future vaccine, proceeded seemingly to push out the CEO who tried to make that deal. They proceeded then to affirm their commitment to international norms of health care distribution that mandate that those most in need will be first to receive any developed treatment. The development of strong and binding international standards will go part of the way to make sure that whatever effective treatments emerge do not become the expensive and exclusive property of those who can pay. The unequal access to health care could intensify or it could be effectively addressed. That is the key point of struggle.

George Yancy: Lastly, there is no rule book that specifies what "public intellectuals" are to do during unprecedented crises like this one. Do you have any suggestions for those of us who might have access to larger public spaces? Then again, perhaps this question is itself symptomatic of a deeper problem that creates a false distinction between "public intellectuals" and those who "are not." Perhaps the question moves us away from what COVID-19 requires - the full critical and loving energy of the demos.

Judith Bulter: My sense is that we have moved from the period of "public intellectuals" to a broader demand for the "public humanities." Many students and recent Ph.Ds. are asking how they can bring their humanities 
backgrounds into public service, how they can overcome the divide between academic and public cultures, and to show how important the humanities are for understanding the world in which we live and making a new path toward a more just and reflective society.

Although some do wait for the anointed public intellectual to speak, most are, in my experience, eager to create conditions for conversation, creative and critical work that expand our ideas about why language, literature, visual arts, history, are important for understanding our world. That world cannot be reduced to "the economy" or "the nation" and neither is it fully defined by the pandemic. A sense of the world can wax and wane, as Ludwig Wittgenstein once said. Whose task is worldmaking in the face of radical disorientation and loss? The rush to Netflix in the midst of ambient death could be understood as a self-anaesthetizing practice, deflecting from reality. But maybe we are drawn to the question of who draws and redraws the world?

Some of the most important insights into devastating historical experiences emerge from stories and images refracted through another time and space. Alexandria
Ocasio-Cortez remarked recently that in one of the districts in Queens she represents, the people speak 200 languages. Translation is a wondrous and critical aspect of the everyday life of that multilingual community. Our public institutions would do well to help us think through different media about persistence and loss, what connects and divides humans across communities, languages and regions, and what role the critical imagination has during times in which crisis and futurity are clearly the issues.

\section{Reference}

Truthout. 2020. Judith Butler: Mourning Is a Political Act Amid the Pandemic and Its Disparities. Truthout, April 30. https://truthout.org/articles/judith-butler-mourning-is-apolitical-act-amid-the-pandemic-and-its-disparities/. Accessed July 31, 2020.

Publisher's note Springer Nature remains neutral with regard to jurisdictional claims in published maps and institutional affiliations. 